\title{
Physiology, phylogeny, and the energetic roots of life
}

\author{
WILLIAM F. MARTIN \\ Institute for Molecular Evolution \\ University of Düsseldorf, Germany. \\ bill@hhu.de
}

\begin{abstract}
Before the days of molecular phylogenies, the standard way of viewing microbial evolution was as process of physiological evolution: the ordering of the sequence of events in which different pathways that microbes use to harness carbon and energy arose. The physiological view of microbial evolution was, of course, replaced in the 1980s by a gene centered view of microbial evolution that was built around the ribosomal RNA tree of life, also called the universal tree or the three domain tree. The universal tree installed long sought order into microbial systematics, but left physiological evolution out in the cold, because physiology never mapped properly onto the rRNA tree. That was not because the universal tree had an incorrect branching pattern. Rather it was because physiological characters have never mapped neatly onto any phylogenetic tree for prokaryotes, regardless of its topology. The reason is that prokaryotes, though they have an undeniable tendency to vertically inherit their ribosome, distribute the physiological traits that enable synthesis of ribosomes via lateral gene transfer (LGT). Geochemical isotope evidence harbors evidence for the existence of physiological processes, not for phylogeny, because LGT decouples physiology from phylogeny in prokaryotes. If we want a fuller picture of microbial evolution, we will have to incorporate aspects of physiology, phylogeny, and the geological record. The issue of how physiology got started has always been interesting. Non-fermentative substrate level phosphorylations as they occur in some acetogens and methanogens now look like good candidate reactions for that starting point, helping to put chemical roots on life's tree.
\end{abstract}

\begin{abstract}
"It may be that for some proteins the evolutionary record in bacteria has been scrambled by the lateral transmission of genes between otherwise unrelated species (although one is not driven to such a conclusion by the data so far available); if so, these case should show up as anomalies in the record and should be recognized when enough proteins have been examined. It may also be that the transfer of linked genes has served to bring respiration to lines of bacteria that never had any photosynthetic ancestors. "Dickerson (1), p. 110.
\end{abstract}

\section{LGT DECOUPLES PHYSIOLOGY FROM PHYLOGENY}

$\mathrm{T}$ The foregoing quote from Dickerson (1) typifies a physiological view of evolution, one in which lateral gene transfer between prokaryotes is normal and distributes metabolic capabilities among lineages. Almost four decades later, the quote is still quite modern. It embodies a particular approach to understanding microbial evolution, a view from the standpoint of physiology - the chemical reactions at the core of carbon and energy metabolism that drive the process of life forward. Physiology
Received September 16, 2016

Revised December 27, 2016.

Accepted December 27, 2016 
is important in evolution, whether carbon $(2,3)$, sulfur $(4,5)$, nitrogen $(6)$, or the geochemical context of physiology (7). Dickerson's quote also puts a very natural and nonchalant 1980s mention of lateral gene transfer (LGT) into the picture of microbial evolution as a common component of genetic variation among prokaryotes, long before people were debating the significance of LGT in prokaryote evolution. It even goes so far as to say that LGT could possibly transform non-respiring lineages into respiring lineages via the transfer of many genes, something that we now know does actually occur during microbial evolution (8).

Dickerson noted that the "evolutionary record“ of microbes might have been scrambled. We have concepts about microbial evolution that are based on their evolutionary record, but what is the evolutionary record of microbes? What is it made of? It would appear that for microbial evolution there are only two kinds of records: geological and genomic. It is said that Earth records its own history (9), so do genomes. Putting geological and genomic evidence into a consistent picture of microbial evolution is a challenging undertaking, but that is the deliverable if we want a fuller picture of microbial evolution. Yet the only real connection between the two kinds of substance of the microbial evolutionary record - rocks and genes - is physiology. Physiology is arguably what life is all about, and the only processes that have left a trace in our current reading of the very ancient geochemical record are physiological.

Rocks preserve evidence of microbial activity in the form of carbon (10), sulfur (11) and nitrogen (12) isotopes, in addition to evidence for molecular oxygen (13). It is the physiological evolution of microbes, not the phylogeny of their ribosomes, that fits into the bigger picture of Earth history. Geologists tell us that the oldest sedimentary rocks, which are ca. 3.8 billion years of age, harbor traces for life in the form of light carbon isotopes, which is generally interpreted as evidence for biological $\mathrm{CO}_{2}$ fixation at that time $(14,15)$, although new findings have it that biological $\mathrm{CO}_{2}$ fixation might go back possibly as far as $4.1 \mathrm{Ga}(16)$. Geologists also tell us that nitrogen fixation has been around for at least 3.2 billion years (12) and that molecular oxygen has been around for about 2.4 billion years $(13,17)$. Rocks date the existence of physiological processes, the distributions of which rarely are restricted to specific phylogenetic groups.

If we look back in the geochemical record beyond roughly 1.5 billion years ago, there are only two kinds of straightforward chemical traces that correspond to evidence for the existence of any modern phylogenetic group. One is the presence of molecular oxygen, which indicates the existence of cyanobacteria 2.4 billion years ago (13). The other is biogenic methane in rocks 3.5 billion years of age, which provides evidence for the antiquity of archaea, because methanogenesis is restricted to the archaea. The antiquity of biological methane does not, however, indicate which groups of methanogens are ancient, because new phylogenetic depictions of the tree of life have methanogens basal among the archaea, with loss of methanogenesis having occurred in many independent groups $(18,19)$, those losses corresponding to gene acquisitions from bacteria in some cases (20). LGT thus decouples phylogeny from physiology in the methanogens, too, which now appear to be the most ancient archaea, but no longer appear as a monophyletic group.

All other physiological traits preserved as isotopic evidence in ancient rocks, whether $\mathrm{CO}_{2}$ reduction $(2,21)$, $\mathrm{N}_{2}$ reduction (22), or sulfur reduction (23), are present in many different prokaryotic groups, both among the archaea and among the bacteria. There can also be little doubt that those physiological traits, regardless of whether they were present in the last universal common ancestor (LUCA) or not, have been distributed by LGT among prokaryotic groups. A clear example is anoxygenic photosynthesis, which operates in conjunction with at least three different $\mathrm{CO}_{2}$ fixation pathways $(13,24)$. Anoxygenic photosynthesis is a major physiological trait, the coding capacity for which entails dozens of genes for the type II photosystem, chlorophyll, and carotenoids. This complex trait can, however, be condensed into a large but mobile plasmid that is colinear with the Rhodobacter photosynthesis operon and that is mobile among marine proteobacteria (25). In microbial evolution, LGT decouples physiology from phylogeny.

\section{Physiology along phylogenies}

Two 1980 papers on microbial evolution appeared in Nature back to back that in some ways symbolize the difference between physiological and phylogenetic views of evolution. The first one, on cytochrome c phylogeny, presented evidence for how LGT played an important role in distributing the gene and physiological attributes associated with it (26). The second one, by Woese et al. (27), presented evidence for congruence between cyctochrome $\mathrm{c}$ and $16 \mathrm{~S} \mathrm{rRNA}$ trees in a more vertically oriented picture of evolution. Of course, $16 S$ sequencing eventually provided the tool and the universally applicable tree that microbial systematics had been looking for. The rRNA tree $(28,29)$ installed direly needed order into microbial systematics. But it left physiological evolution out in the cold, because physiology never mapped properly onto any incarnation of the rRNA tree.

To be sure, we need prokaryotic systematics. It is also hard at present to imagine a kind of prokaryotic systematics that is not based, at higher taxonomic levels, on ribosomal phylogeny. There also are good reasons to think that the ribosome is inherited vertically in prokaryotes (30). After all, an E. coli cell is about $16 \%$ ribosomal RNA by dry weight (31) and a ribosome is about $40 \%$ protein by weight, such that if we take $E$. coli as a typical prokaryote, ribosomes make up about one third of the dry weight of a cell. If we get the phylogeny of a cell's ribosomes right, 
we would have a picture of how a major component of the cell evolved over time. The ribosome requires, however, the physiology of the cell (carbon, nitrogen, sulfur and energy) to make it from one generation to the next.

Even for newer versions of the rRNA tree based on ribosomal proteins rather than ribosomal RNA (32), the sporadic distribution of traits like photosynthesis shows that their distributions do not follow phylogeny, rather they are the result of LGT. As technology progressed through the 1990s up to today, it became very easy and affordable to sequence genes, then genomes, then genomes of environments. The computer power to handle such data kept pace with the leaps in sequencing technology accordingly. But the pursuit of genes and genomes has led us into a situation where, thanks to modern environmental sequencing, we now have genome-supported trees for hundreds and thousands of previously undiscovered prokaryotes, but we do not know what they need and how they grow, their physiology. Environmental genomes reflect fascinating organisms in fascinating environments, but in order to understand their environmental significance, we need to know what they are doing for a living $(19,32)$. That is not a criticism of environmental sequencing, it is a plea for understanding physiology.

It is not as easy as one might have thought to piece together what the organisms that belong to environmental sequences are doing in nature based on the information in their genome. An example are the methanogenlike metabolisms that people are finding in marine sediments. Evans et al. (19) reported new archaeal lineages (Bathyarchaeota) from marine sediment that have the archaeal version of the acetyl-CoA pathway, but have no clear evidence for known forms of archaeal energy conserving metabolism. He et al. (33) reported Bathyarchaeota lineages that appear to be performing a very simple and suspected primitive form of energy metabolism that is otherwise only known from bacteria so far - or from archaea under very specific kinds of culture conditions (34) - acetogenesis.

For the currently unculturable organisms, environmental sequencing is presently the only avenue of pursuit. There might come a time when we have made trees for all there is that will fit on a tree. Maybe then there will be a return to physiology in understanding the microbial evolutionary process, regardless of whether it maps out neatly on a tree or not. Advances in physiology do not, however, come an environment at a time, they generally come one protein, one enzyme, one enzyme complex and one reaction at a time. Progress in physiology can therefore be slow, as demonstrated by the example of anaerobic methane oxidizers. They were imaged 16 years ago (35), but still no one can yet sort our exactly how they work (36, 37), that is, how they pump and which chemical reactions are involved $(38,39)$. Even if we sort out how all of the organisms covered in today's metagenomics pump and exactly where the electrons in their core physiology come and go, that still would by itself answer to the question of where those reactions fit in the bigger picture of physiological evolution. That brings us back to Dickerson's 1980 paper quoted in the introduction (1), the overall course of physiological evolution, and (finally some readers might say) the question in the title of this paper of how physiological evolution got started. What kind of carbon and energy metabolism existed at the root of life's tree?

\section{Fermentation at the root?}

In evolutionary biology, when we want to reconstruct or address unknown sequences of events in the biological past, the standard protocol is to start from what we presume to be the simple and to work forward in time with the help of natural variation and natural selection towards the more complex, without violating the dicta of natural science and paying attention to Occam's razor. Using such tools in the context of physiology, scientists interested in the first kinds of metabolism have long thought that fermentations are the logical starting point for physiological evolution $(40,41)$. Haldane $(40$, p. 8$)$ formulated it like this:

„To-day an organism must trust its luck, skill, or strength to obtain its food. The first precursors of life found food available in considerable quantities and had no competitors in the struggle for existence. As the primitive atmosphere contained little or no oxygen, they must have obtained the energy which they needed for growth by some other process than oxidation - in fact by fermentation."

Of course, in Haldane's day, nobody knew how fermentations work. Fermentations of the kind that anyone ever had in mind in an early metabolism context are disproportionation reactions of carbon in an organic compound like glucose. Starting from an intermediate oxidation state, the carbon is converted into a more oxidized form, like $\mathrm{CO}_{2}$ (or the carboxyl group in lactate) and a more reduced form like ethanol (or the methyl group in lactate). Because glucose is an energy rich compound, there is energy to be gleaned from ethanol or lactate fermentations, enough to generate one ATP per $\mathrm{CO}_{2}$ (or carboxylate) produced, the energy being conserved at an oxidative step in which an aldehyde group is converted into a carboxyl group via an enzyme bound hemithioacetal, its oxidation to an energy rich thioester, phosphorolysis of which releases an acyl phosphate with a free energy of hydrolysis high enough to readily phosphorylate any number of compounds, including the beta phosphate on ADP. Many other kinds of fermentations exist (42, 43, $44)$. But can such a reaction sequence reside at life's root?

A very surprising development in fermentations concerns the mechanisms of energy conservation. In eukaryotes, energy conservation during fermentations is typically a straightforward process of substrate level phosphorylation: during conversions of small molecular weight carbon compounds, the energy in a thioester bond or an acyl phosphate bond is conserved to generate ATP 
(45). In strictly anaerobic prokaryotes (the ones that are likely to be ancient, also in Haldane's view), fermentations involve chemiosmotic coupling $(46,47,48,49,50)$. In phylogenetic terms, eukaryotes arose from prokaryotes via endosymbiosis, such that in physiological evolution, the eukaryotic kinds of fermentation cannot be the ancestral state. Can fermentations that involve chemiosmotic coupling be the ancestral state of physiology? Probably not, because a relatively large number of proteins properly arranged in the plasma membrane are required to create chemiosmotic gradients via ion pumping coupled to exergonic reactions (usually redox reactions) and to harness chemiosmotic gradients via rotor stator type ATPases. The ATPase is as ancient as the ribosome, yes (51), and it is less complex than the ribosome. The issue is not "what is possible once we have ribosomes", the issue is more „what kind of physiology underpinned the origin of the ribosome?"

The closer we look, the more evident it becomes that fermentations are actually a very problematic starting point for physiological evolution altogether. The main problem concerns substrate. Fermentations as they exist in the cells whose origin we strive to explain involve channeling a very small number of substrates (often just one) present in large amounts through a very specific series of conversions leading to one highly tuned reaction sequence catalyzed by a handful of 3-4 enzymes that conserve energy as a compound that can phosphorylate ATP. At the onset of evolution, there were no environmental reserves of reduced carbon compound present in large amounts as specific isomers that could have fuelled energy conservation via fermentations or promoted their origin from the elements.

On the early, uninhabited Earth, the main form of carbon was not glucose, glucose phosphate, ribose, glycogen, or starch, it was $\mathrm{CO}_{2}(52)$. That is because the early Earth went through a phase where the planet was molten rock and metal, which is typically hotter than $1000^{\circ} \mathrm{C}$ and carbon in contact with the elements on the early Earth at such temperatures will exist as $\mathrm{CO}_{2}$, not as glucose or anything similar. Critics will interject, but what about carbon from space? Yes, there was a lot of carbon brought to Earth from meteorites, maybe 10\% of Earth's total carbon (53), but the carbon in meteorites has a different problem: it is too reduced. Carbon in meteorites is typically on the order of $98 \%$ polyaromatic hydrocarbons (54), which are basically graphite, a nonfermentable substrate. The remaining $2 \%$ is distributed across hundreds (or thousands) of different compounds, mostly various isomers of aliphatic acids, each present in parts per million or parts per billion concentrations. Straight or branched chain organic acids are also nonfermentable substrates, they are too reduced for disproportionation. Remaining components of stardust, present in trace concentrations each, might be fermentable in terms of their redox state - amino acids and bases are fermentable for example (42)
- but would require dozens or hundreds of preexisting isomerases and mutases in order to channel substrates into reactions suitable for harnessing via substrate level phosphorylation (SLP). Stardust delivers reduced carbon compounds, but not fermentable substrates (50).

Avoiding the fermentation problem by throwing in some oxidants like $\mathrm{Fe}^{3+}$ (55) or $\mathrm{NO}$ (56) to harness chemical energy by oxidizing nonfermentable substrates (instead of disproportionation reactions) does not remedy the situation. That is because in the presence of strong oxidants, carbon equilibrium lies in the side of $\mathrm{CO}_{2}$, not on the side of the building blocks of life (57). In the presence of strong oxidants, the chemical substance of life will be oxidized to $\mathrm{CO}_{2}(24)$.

\section{If not fermentation first, what then?}

If substrate level phosphorylation via fermentations at the onset of energy metabolism won't work, what will? Since mid-1980s, Georg Fuchs had repeatedly made the case that the acetyl CoA pathway was the most ancient pathway of $\mathrm{CO}_{2}$ fixation $(2,58,59)$. But the acetyl-CoA pathway is also a pathway of energy metabolism. Everett Shock (60) said it one way: organisms that use acetyl-CoA pathway „get a free lunch that they are paid to eat". Rolf Thauer, in an enlightening conversation, said it another way: in the reaction of $\mathrm{H}_{2}$ and $\mathrm{CO}_{2}$, the equilibrium lies on the side of acetate.

That is perhaps the main reason why hydrothermal vents are attractive as the site of physiological origin. $\mathrm{H}_{2}$ is continuously generated in the crust via the process of serpentinization $(61,62,63)$, it exits in hydrothermal vents at concentrations exceeding $10 \mathrm{mM}$, interfaces with large amounts of $\mathrm{CO}_{2}$ in the ancient oceans, which contained more $\mathrm{CO}_{2}$ than today, perhaps $1000 \mathrm{x}$ as much (64). Some modern cells harness energy from the reaction of $\mathrm{H}_{2}$ with $\mathrm{CO}_{2}$, satisfying their carbon and energy needs from $\mathrm{H}_{2}$ and $\mathrm{CO}_{2}$ alone: acetogens (bacteria) and methanogens (archaea). They are both chemiosmotic in that they reduce $\mathrm{CO}_{2}$ with electrons from $\mathrm{H}_{2}$, pumping protons or sodium ions in the process. Their ATPases are related, their mechanisms of pumping are not $(65,46,47$, 66). Serpentinization also generates alkaline water (67) such that at the vent-ocean interface a proton gradient exists. A case can be made that the first replicating chemical systems possessing genes and the genetic code could harness geochemical ion gradients (68). But that still cannot be the beginning of physiology, because if that replicating system had genes and the code, then it had to have possessed a form of physiology that supported its heritable replication. How did physiology get going? Neither SLP via fermentations can be the first energy metabolism for lack of fermentable substrates (50), nor can chemiosmotic harnessing to conserve energy as ATP because that requires proteins as energy converters in all forms of life known (the only ones we have to explain). What possi- 
bilities are then left to choose from? If we look around at what is known among real microbes, the only alternative that this author can see that exists in modern metabolism, is that physiology got started through a kind of SLP that does not depend upon fermentation: the kind of SLP that is manifest in some autotrophs that employ the acetylCoA pathway, also called the Wood-Ljungdahl pathway (69). Under standard physiological conditions, the acetylCoA pathway generates a thioester in the exergonic reaction of $\mathrm{H}_{2}, \mathrm{CO}_{2}$ and a thiol

$$
2 \mathrm{CO}_{2}+4 \mathrm{H}_{2}+\mathrm{CoASH} \rightarrow \mathrm{CH}_{3} \mathrm{COSCoA}+3 \mathrm{H}_{2} \mathrm{O}
$$

with $\Delta G_{\mathrm{o}}{ }^{\prime}=-59.2 \mathrm{~kJ} / \mathrm{mol}(70)$. In acetogens (2) and in the methanogen Methanosarcina mazei under specific growth conditions - namely on CO (34) - the thioester undergoes phosphorolysis to acetyl phosphate

$$
\begin{gathered}
\mathrm{CH}_{3} \mathrm{CO} \sim \mathrm{SCoA}+\mathrm{HOPO}_{3}^{2-} \rightarrow \mathrm{CH}_{3} \mathrm{CO} \sim \mathrm{OPO}_{3}{ }^{2-}+ \\
\mathrm{CoASH}
\end{gathered}
$$

with $\Delta G_{\mathrm{o}}{ }^{\prime}=+10.5 \mathrm{~kJ} / \mathrm{mol}(44)$. The mixed anhydride is an excellent phosphoryl donor with a free energy of hydrolysis

$$
\mathrm{CH}_{3} \mathrm{CO} \sim \mathrm{OPO}_{3}{ }^{2-}+\mathrm{H}_{2} \mathrm{O} \rightarrow \mathrm{CH}_{3} \mathrm{COO}^{-}+\mathrm{HOPO}_{3}{ }^{2-}
$$

of $\Delta G_{\mathrm{o}}{ }^{\prime}=-43 \mathrm{~kJ} / \mathrm{mol}(71)$, higher than that of $\operatorname{ATP}\left(\Delta G_{\mathrm{o}}{ }^{\prime}\right.$ $=-31 \mathrm{~kJ} / \mathrm{mol}(71)$, such that the ATP is readily synthesized from acetyl-phosphate

$$
\mathrm{CH}_{3} \mathrm{CO} \sim \mathrm{OPO}_{3}^{2-}+\mathrm{ADP} \rightarrow \mathrm{CH}_{3} \mathrm{COO}^{-}+\mathrm{ATP}
$$

with $\Delta G_{\mathrm{o}}{ }^{\prime}=-10.5 \mathrm{~kJ} / \mathrm{mol}$ (44) via SLP. The two enzyme system that catalyzes this reaction in acetogens and in many bacteria, phosphotransacetylase and acetate kinase, also occurs in Methanosarcina mazei (34) yet is missing in most methanogens and in most archaea studied so far (50). Archaea tend to use a different and unrelated enzyme for ATP synthesis via SLP from acetyl-CoA. The archaeal enzyme, acetyl-CoA synthase (ADP forming), follows the same simple chemistry as the bacterial route, but the acyl phosphate remains enzyme bound throughout the reaction (72). The term „SLP“ at the bottom of Figure 1 refers to the sequence of reactions just outlined and several papers that argued for the antiquity of this reaction sequence based on physiological or thermodynamic observations $(2,21,60,62,73,74)$.

\section{An old figure with a new root.}

The "problem" with acetogen and methanogen physiology is that there is not enough energy in the reaction of $\mathrm{H}_{2}$ with $\mathrm{CO}_{2}$ to either acetate or methane to supply carbon as acetyl-CoA and to simultaneously support growth via SLP. That is why growth of both acetogens and methanogens on $\mathrm{H}_{2}$ and $\mathrm{CO}_{2}$ strictly requires chemiosmosis (pumping), which allows the energy of a mildly exergonic reaction to be stored in the currency of an ion gradient for chemiosmotic energy harnessing. Acetogens growing on $\mathrm{H}_{2}$ and $\mathrm{CO}_{2}$ reduce 24 molecules of $\mathrm{CO}_{2}$ to acetate for every molecule of $\mathrm{CO}_{2}$ that they incorporate as cell

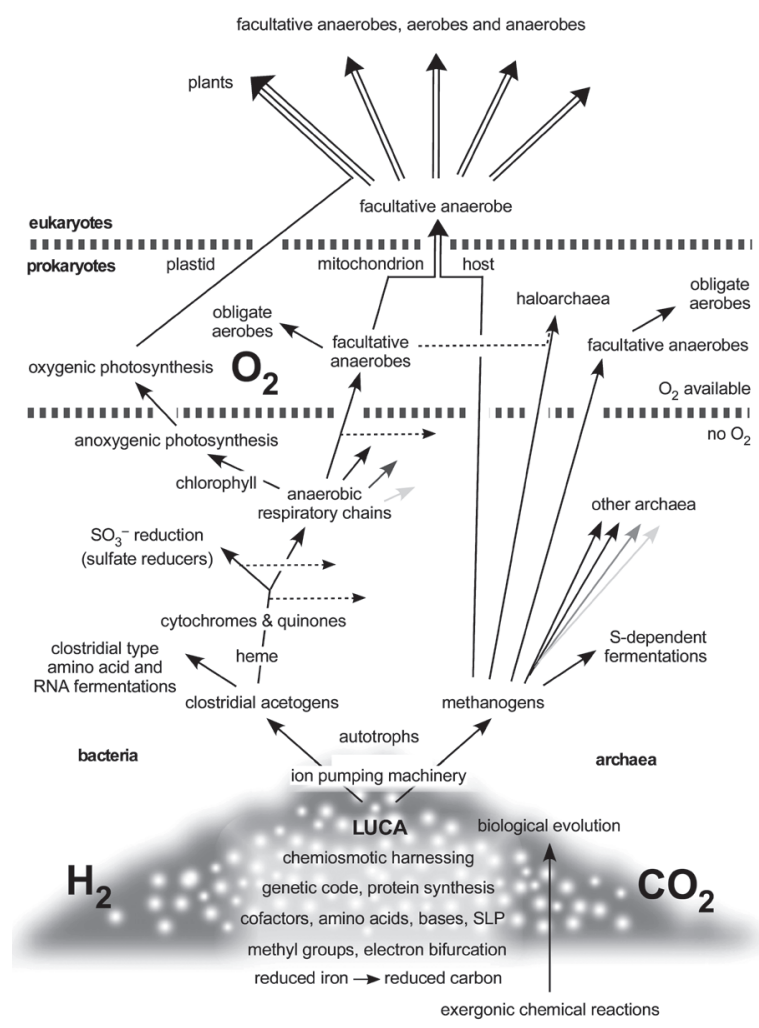

Figure 1. Physiology and phylogeny in life's tree. The figure combines aspects of several papers: Decker et al. (44) from 1970, Dickerson (1) from 1980, Martin and Russell (62, 73), Martin (99), Müller et al. (45), Lane and Martin (68), Nelson-Sathi et al. (8), Sousa et al. (24), Sousa and Martin (100), Schönheit et al. (50), Fischer et al. (13), Martin et al. (101), Sousa et al. (88), Weiss et al. (77). Line lengths are not proportional to time. Dotted lines symbolize LGT. Parallel lines symbiolize endosymbiosis.

mass (75), while methanogens that lack cytochromes, growing from a slightly more exergonic reaction, reduce about 20 molecules of $\mathrm{CO}_{2}$ to methane for every molecule of $\mathrm{CO}_{2}$ that they incorporate as cell mass, which can be estimated from the numbers given in Thauer et al. (65). The requirement for chemiosmotic pumping in the free living lifestyle of acetogens and methanogens, which survive on some of the lowest free energy changes known (76) is indicated in the figure as the advent of ,ion pumping machinery". The pumping machineries in acetogens and methanogens are apparently a parallel invention in the bacterial and archaeal lineages (68), while the ability to harness naturally existing (geochemical) ion gradients apparently traces to $\operatorname{LUCA}(51,62,68,77)$.

An important new development in understanding the physiology of anaerobes is flavin based electron bifurcation, a mechanism of energy conservation discovered in $2008(78,79)$ and now known to be common to many strict anaerobes (80). In electron bifurcation, an electron pair is split, with the individual electrons going in two different directions, one typically going energetically up- 
hill to a low potential acceptor, but not for free, of course, because the other electron picks up the thermodynamic tab via transfer to a high potential acceptor such that the overall reaction is energetically downhill (40). The discovery of electron bifurcation was very important, because it solved many nagging but crucial problems in the physiology of anaerobes, from odd stoichiometries among end products (81), to pressing questions of how methanogens and acetogens generate low potential ferredoxins having a midpoint potential around $-500 \mathrm{mV}$ from $\mathrm{H}_{2}$ the midpoint potential of which is not sufficiently negative $(-414 \mathrm{mV})$ to allow the reaction to go forward (82). By transferring one electron from $\mathrm{H}_{2}$ downhill to a heterodisulfide acceptor with $\mathrm{E}_{0}{ }^{\prime}=-140 \mathrm{mV}$, the overall energetics of the reaction are favorable (82). Electrons can also confurcate, which is how Thermotoga generates $\mathrm{H}_{2}$ from NADH (which thermodynamically should not work), the trick being that the hydrogenase obtains one electron from $\mathrm{NADH}$ and the other from a low potential ferredoxin, which makes the overall reaction favorable (83). Flavin based electron bifurcation is a new development in bioenergetics $(80)$. Some might debate the view that electron bifurcation is a mechanism of energy conservation because it does not directly result in ATP synthesis, but it results in the synthesis of low potential ferredoxin, which can be seen as a kind of energy currency (78), like acyl phosphates (84) or thioesters (55).

Aside from the foregoing somewhat lengthy justification for replacing fermentation at the root of physiology with fermentation-independent SLP, and except for a few other aspects that are mentioned in the figure legend, the overall outline of Figure 1 looks very similar to figures in Dickerson (1) and Decker et al. (44). The reason is not lacking ability to draw my own figures, but because those two papers presented pictures of physiological evolution that, seen from my perspective, have not changed dramatically in the decades since they first appeared.

In fact, it seems that views of physiological evolution have changed very little in general during the last 30 years, far less than views about phylogeny have changed (views about phylogeny have an inherently high rate of change). During that time, my interest has been to try to understand gene phylogenies in the context of physiology and evolution, as I will summarize in this paragraph (the reader is asked to excuse self-citations). Anaerobes are still ancient, oxygen still comes late and is of biogenic (cyanobacterial) origin, appearing about 2.4 billion years ago in the geochemical record $(13,26)$. As in 1970, sulfate reducers still are ancient, and clostridia and methanogens are more ancient yet $(44,77)$. (In 1970, archaea had not even been discovered such that a modern-context discussion of endosymbiosis was moot.) The endosymbiotic origin of organelles is still important $(26,85)$, although the host for the origin of mitochondria now better seen as an archaeon $(86,87,88)$. Curiously, in 1980 there were no well-founded physiological views on the host, Van Va- len and Maiorana (89) being a major exception, but like everyone else, they had their tree of physiological evolution rooted in fermentations, which we now see (50) will not work. Anoxygenic photosynthesis still precedes oxygenic photosynthesis $(26,90)$. Lateral gene transfer plays a role in physiological evolution $(1,91)$, also massive LGT capable of introducing respiration into an otherwise nonrespiring lineage (26), namely the transformation of methanogens into haloarchaea $(8,20)$, and the transformation of a $\mathrm{H}_{2}$-dependent archaeal host into a facultative anaerobic eukaryote harbouring the common ancestor of mitochondria and hydrogenosomes $(45,86,92,93)$, a lineage of which acquired the cyanobacterial ancestor of plastids (94) and many genes from that plastid ancestor (95, 96). In my studies of genes, I have been trying to let each gene speak for itself as best it can with phylogenetic tools and I have been trying to interpret the message of as many genes as possible, rather than looking at one or a few genes in the hope, expectation, or conviction that those I, or others, select will speak for the whole genome.

\section{Schluss.}

Schluss is a German word that means end or conclusion, I choose it here because Mereschkowsky used it to conclude some of his papers, and he was also trying to understand physiological evolution, which led him straight to the conclusion that plastids were once free-living cyanobacteria. It is also interesting to note that he did not view the evolution of physiology as starting from fermentations, rather he suggested over 100 years ago that the first cells had the ability to synthesize proteins and carbohydrates (the latter without the help of chlorophyll) from inorganic substances ['Fähigkeit, Eiweiße und Koblenhydrate (letzteres ohne Vermittlung des Chlorophylls) aus unorganischen Stoffen zu bilden.' (Mereschkowsky (97), p. 360)], which today we would call autotrophic origins.

Mereschkowsky was using endosymbiosis to explain physiological phenomena (photosynthesis in plants). Endosymbiosis is about physiology, not about genes or genetics. But views of evolution that focused on genes or genetics never had much room for endosymbiosis, possibly because it was about physiology, not genes, possibly because physiology is chemistry and does not fit into the mathematical mold of evolutionary genetics. We need genetics to understand evolution, yes, but without carbon and energy metabolism to run the processes of genetics and keep organisms alive over a generation or overnight, no evolution can take place. At life's origin, genes came from a physiological process of chemical synthesis, genes are products (byproducts, actually) of an ancient, exergonic core chemical reaction. That is still true about life today.

One more aspect comes to mind in the present context. One of the more serious problems with the idea that life started off with fermentations concerns heterogeneity of substrates. Carbon from space is not a fermentable substrate, and even if we were to imagine that $\mathrm{CO}_{2}$ reduction 
in hydrothermal systems (or elsewhere) led to a kind of organic soup containing high concentrations of compounds that could undergo disproportionations in such a way as to support fermentation, there is no reason to think that such a soup would be sufficiently homogeneous in composition to support a metabolic process for any prolonged period of time. This line of thinking unveils a subtle elegance of SLP via $\mathrm{CO}_{2}$ reduction at physiological origin: The reduction of $\mathrm{CO}_{2}$ under geochemical conditions generates a very simple and uniform sequence of chemical compounds: $\mathrm{CO}$, formate, formyl groups, and methyl groups (and finally methane which is very stable). $\mathrm{CO}$ is rare in biology, except as a ligand in hydrogenases and as an apparently irreplaceable intermediate in the acetyl-CoA pathway during growth on $\mathrm{H}_{2}$ and $\mathrm{CO}_{2}$. $\mathrm{CO}_{2}$, formate and formyl groups (usually pterin-bound) are quite common across biological chemistry, and methyl groups are very common, being particularly common in the modified bases that allow the genetic code to work (77), in addition to their central role in the carbon and energy metabolism of acetogens and methanogens. The ways that carbon enters metabolism probably holds clues about how metabolism got started, if we look at the right kinds of organisms (modern anaerobic chemolithoautotrophs, I maintain).

The point is this. The path starting from $\mathrm{CO}_{2}$ to the molecules of life traverses a very finite number of routes, exergonic routes harboring energy that the most primitive kinds of prokaryotes still harness in today during growth. Those reactions, some of which still take place in hydrothermal systems today (98), seem both simpler and more ancient that the enzymes that catalyze them, which fits well with physiological thinking in evolution, because enzymes do not perform feats of magic, they just accelerate reactions that tend to occur anyway. The finite number and nature of exergonic reactions from $\mathrm{CO}_{2}$ to the core of carbon and energy metabolism in anaerobic autotrophs (thioesters and acyl phosphates) is determined by the properties of carbon itself and the catalysts with which it interacts.

All things considered, $\mathrm{CO}_{2}$ is an excellent carbon and energy substrate at the origin of physiology. It was undisputedly available in abundance on the early Earth and it is a chemically simple source of energy in conjunction with $\mathrm{H}_{2}$ (also undisputedly abundant in early serpentinizing systems). It has short, direct, and thermodynamically favored reaction pathways with sulfur and phosphate in modern physiology that can conserve energy in thioester and acyl phosphate bonds. The nature of SLP in conjunction with the acetyl-CoA pathway is, however, neither fermentative nor respiratory, it is anabolic. Modern anaerobic autotrophs use electron bifurcation (46) to generate ferredoxins with midpoint potentials lower than that of $\mathrm{H}_{2}$ to reduce $\mathrm{CO}_{2}$, pointing to a role for reduced iron itself at the root of $\mathrm{CO}_{2}$ reduction and early physiological evolution (Figure 1) that is even more ancient than that of $\mathrm{H}_{2}$.
Acknowledgement: I thank Verena Zimorski for help in preparing the manuscript, the ERC (AdvGr 666053) for financial support, many friends and colleagues for discussions, $H D B M B$ for their kind hospitality during meetings and Damjan Franjevic for the invitation to contribute here.

\section{REFERENCES}

1. DICKERSON RE 1980 Cytochrome $\mathrm{c}$ and the evolution of energy metabolism. Sci Am 242: 98-110.

https://doi.org/10.1038/scientificamerican0380-136

2. FUCHS G 2011 Alternative pathways of carbon dioxide fixation: Insights into the early evolution of life? Annu Rev Microbiol 65: 631-658. http://dx.doi.org/10.1146/annurev-micro-090110-102801

3. BRÄSEN C, ESSER D, RAUCH B, SIEBERS B 2014 Carbohydrate metabolism in archaea: Current insights into unusual enzymes and pathways and their regulation. Microbiol Mol Biol Rev 78: 89-175. http://dx.doi.org/10.1128/MMBR.00041-13

4. LIU Y, BEER LL, WHITMAN WB 2012 Methanogens: A window into ancient sulfur metabolism. Trends Microbiol 20: 251-258. http://dx.doi.org/10.1016/j.tim.2012.02.002

5. SANTOS AA, VENCESLAU SS, GREIN F, LEAVITT WD, DAHL C, JOHNSTON DT, PEREIRA IAC 2015 A protein trisulfide couples dissimilatory sulfate reduction to energy conservation. Science 350: 1541-1545. http://dx.doi.org/10.1126/science.aad3558

6. HU Y, RIBBE MW 2015 Nitrogenase and homologs. J Biol Inorg Chem 20: 435-445. http://dx.doi.org/10.1007/s00775-014-1225-3

7. SHOCK EL, BOYD ES 2015 Principles of geobiochemistry. Elements 11: 395-401. http://dx.doi.org/10.2113/gselements.11.6.395

8. NELSON-SATHI S, DAGAN T, LANDAN G, JANSSEN A, STEEL M, MCINERNEY JO, DEPPENMEIER U, MARTIN WF 2012 Acquisition of 1,000 eubacterial genes physiologically transformed a methanogen at the origin of Haloarchaea. Proc Natl Acad Sci US A 109: 20537-20542.

http://dx.doi.org/10.1073/pnas.1209119109

9. GAIDOS E, KNOLL AH 2012 Our evolving planet: From dark ages to evolutionary renaissance. In: Impey C, Lunine J, Funes J (eds) Frontiers of Astrobiology. Cambridge University Press, Cambridge, pp. 132-153. https://doi.org/10.1017/CBO9780511902574.011

10. UENO Y, YAMADA K, YOSHIDA N, MARUYAMA S, ISOZAKI Y 2006 Evidence from fluid inclusions for microbial methanogenesis in the early archaean era. Nature 440: 516-519. http://dx.doi.org/10.1038/nature04584

11. POULTON SW, FRALICK PW, CANFIELD DE 2004 The transition to a sulphidic ocean similar to 1.84 billion years ago. Nature 431: 173-177. http://dx.doi.org/10.1038/nature02912

12. STÜECKEN EE, BUICK R, GUY BM, KOEHLER MC 2015 Isotopic evidence for biological nitrogen fixation by molybdenum-nitrogenase from 3.2 Gyr. Nature 520: 666-669.

http://dx.doi.org/10.1038/nature14180

13. FISCHER WW, HEMP J, JOHNSON JE 2016 Evolution of oxygenic photosynthesis. Ann Rev Earth Planet Sci 44: 647-683. http://dx.doi.org/10.1146/annurev-earth-060313-054810

14. MOJZSIS SJ, ARRHENIUS G, MCKEEGAN KD, HARRISON TM, NUTMAN AP, FRIEND CR 1996 Evidence for life on Earth before 3,800 million years ago. Nature 384: 55-59. http://dx.doi.org/10.1038/384055a0

15. UENO Y, YURIMOTO H, YOSHIOKA H, KOMIYA T, MARUYAMA S 2002 Ion microprobe analysis of graphite from ca. 3.8 Ga metasediments, Isua crustal belt, West Greenland: Relationship between metamorphism and carbon isotopic composition. Geochimia et Cosmochimia Acta 66: 1257-1268. http://dx.doi.org/10.1016/S0016-7037(01)00840-7 
16. BELL EA, BOEHNKE P, HARRISON TM, MAO WL 2015 Potentially biogenic carbon preserved in a 4.1 billion-year-old zircon. Proc Nat Acad Sci U S A 112: 14518-14521. http://dx.doi.org/10.1073/pnas.1517557112

17. LYONS TW, REINHARD CT, PLANAVSKY NJ 2014 The rise of oxygen in Earth's early ocean and atmosphere. Nature 506: 307-315. http://dx.doi.org/10.1038/nature13068

18. RAYMANN K, BROCHIER-ARMANET C, GRIBALDO S 2015 The two-domain tree of life is linked to a new root for the Archaea. Proc Nat Acad Sci U S A 112: 6670-6675. http://dx.doi.org/10.1073/pnas.1420858112

19. EVANS PN, PARKS DH, CHADWICK GL, ROBBINS SJ, ORPHAN VJ, GOLDING SD, TYSON GW 2015 Methane metabolism in the archaeal phylum Bathyarchaeota revealed by genomecentric metagenomics. Science 350: 434-438.

http://dx.doi.org/10.1126/science.aac7745

20. NELSON-SATHI S, SOUSA FL, ROETTGER M, LOZADACHÁVEZ N, THIERGART T, JANSSEN A, BRYANT D, LANDAN G, SCHÖNHEIT P, SIEBERS B, MCINERNEY JO, MARTIN WF 2015 Origins of major archaeal clades correspond to gene acquisitions from bacteria. Nature 517: 77-80. http://dx.doi.org/10.1038/nature13805

21. BERG IA, KOCKELKORN D, RAMOS-VERA WH, SAY RF, ZARZYCKI J, HÜGLER M, ALBER BE, FUCHS G 2010 Autotrophic carbon fixation in archaea. Nat Rev Microbiol 8: 447-460. http://dx.doi.org/10.1038/nrmicro2365

22. ZEHR JP, WATERBURY JB, TURNER PJ, MONTOYA JP, OMOREGIE E, STEWARD GF, HANSEN A, KARL DM 2001 Unicellular cyanobacteria fix $\mathrm{N}_{2}$ in the subtropical North Pacific Ocean. Nature 412: 635-638. http://dx.doi.org/10.1038/35088063

23. RABUS R, VENCESLAU SS, WÖHLBRAND L, VOORDOUW G, WALL JD, PEREIRA IAC 2015 A post-genomic view of the ecophysiology, catabolism and biotechnological relevance of sulphate-reducing prokaryotes. Adv Microb Physiol 66: 55-321. http://dx.doi.org/10.1016/bs.ampbs.2015.05.002

24. SOUSA FL, THIERGART T, LANDAN G, NELSON-SATHI S, PEREIRA IAC, ALLEN JF, LANE N, MARTIN WF 2013 Early bioenergetic evolution. Philos Trans R Soc Lond B 368: 20130088. http://dx.doi.org/10.1098/rstb.2013.0088

25. PETERSEN J, FRANK O, GÖKER M, PRADELLA S 2013 Extrachromosomal, extraordinary and essential - The plasmids of the Roseobacter clade. Appl Microbiol Biotechnol 97: 2805-2815. http://dx.doi.org/10.1007/s00253-013-4746-8

26. DICKERSON RE 1980 Evolution and gene transfer in purple photosynthetic bacteria. Nature 283: 210-212.

27. WOESE CR, GIBSON J, FOX GE 1980 Do genealogical partterns in photosynthetic bacteria reflect interspecific gene transfer? Nature 283: 212-214. https://doi.org/10.1038/283212a0

28. FOX G, STACKEBRANDT E, HESPELL R, GIBSON J, MANILOFF J, DYER T, WOLF R, BALCH W, TANNER R, MAGRUM L, ZABLEN L, BLEKEMORE R, GUPTA R, BONEN L, LEWIS B, STAHL D, LUEHRSEN K, CHEN K, WOESE C 1980 The phylogeny of prokaryotes. Science 209: 457-463. https://doi.org/10.1126/science.6771870

29. WOESE C, KANDLER O, WHEELIS ML 1990 Towards a natural system of organisms: Proposal for the domains Archaea, Bacteria and Eukarya. Proc Natl Acad Sci U S A 87: 4576-4579. https://doi.org/10.1073/pnas.87.12.4576

30. JAIN R, RIVERA MC, LAKE JA 1999 Horizontal gene transfer among genomes: The complexity hypothesis. Proc Natl Acad Sci US A 96: 3801-3806. http://dx.doi.org/10.1073/pnas.96.7.3801

31. NEIDHARDT FC, INGRAHAM JL, SCHAECHTER M (eds) 1990 Physiology of the Bacterial Cell - A molecular approach. Sinauer Associates, Sunderland, MA.
32. HUG LA, BAKER BJ, ANANTHARAMAN K, BROWN CT, PROBST AJ, CASTELLE CJ, BUTTERFIELD CN, HERNSDORF AW, AMANO Y, ISE K, SUZUKI Y, DUDEK N, RELMAN DA, FINSTAD KM, AMUNDSON R, THOMAS BC, BANFIELD JF 2016 A new view of the tree of life. Nat Microbiol 1: 16048. http://dx.doi.org/10.1038/nmicrobiol.2016.48

33. HE Y, LI M, PERUMAL V, FENG X, FANG J, XIE J, SIEVERT SM, WANG F 2016 Genomic and enzymatic evidence for acetogenesis among multiple lineages of the archaeal phylum Bathyarchaeota widespread in marine sediments. Nat Microbiol 1: 16035. http://dx.doi.org/10.1038/nmicrobiol.2016.35

34. ROTHER M, METCALF WW 2004 Anaerobic growth of Methanosarcina acetivorans $\mathrm{C} 2 \mathrm{~A}$ on carbon monoxide: An unusual way of life for a methanogenic archaeon. Proc Natl Acad Sci US A 101: 16929-16934. http://dx.doi.org/10.1073/pnas.0407486101

35. BOETIUS A, RAVENSCHLAG K, SCHUBERT CJ, RICKERT D, WIDDEL F, GLESEKE A, AMANN R, JORGENSEN BB, WITTE U, PFANNKUCHE O 2000 A marine microbial consortium apparently mediating anaerobic oxidation of methane. Nature 407: 623-626. http://dx.doi.org/10.1038/35036572

36. WEGENER G, KRUKENBERG V, RIEDEL D, TEGETMEYER HE, BOETIUS A 2015 Intercellular wiring enables electron transfer between methanotrophic archaea and bacteria. Nature 526: $587-$ 590. https://doi.org/10.1038/nature15733

37. MCGLYNN SE, CHADWICK GL, KEMPES CP, ORPHAN VJ 2016 Single cell activity reveals direct electron transfer in methanotrophic consortia. Nature 526: 531-535. http://dx.doi.org/10.1038/nature15512

38. HOLLER T, WEGENER G, NIEMANN H, DEUSNER C, FERDELMAN TG, BEOTIUS A, BRUNNER B, WIDDEL F 2011 Carbon and sulfur back flux during anaerobic microbial oxidation of methane and coupled sulfate reduction. Proc Natl Acad Sci US A 108: E1484-1490. http://dx.doi.org/10.1073/pnas.1106032108

39. MILUCKA J, FERDELMAN TG, POLERECKY L, FRANZKE D, WEGENER G, SCHMID M, LIEBERWIRTH I, WAGNER M, WIDDEL F, KUYPERS MM 2012 Zero-valent sulphur is a key intermediate in marine methane oxidation. Nature 491: 541-546. http://dx.doi.org/10.1038/nature11656

40. HALDANE JBS 1929 The origin of life. Rationalist Annu. 3-10.

41. SAGAN L 1967 On the origin of mitosing cells. J Theoret Biol 14: 225-274. https://doi.org/10.1016/0022-5193(67)90079-3

42. BARKER HA 1961 Fermentation of nitrogenous compounds. In: Gunsalus IC, Stanier RY (eds) The Bacteria. A Treatise on Structure and Function. Academic Press, New York, pp. 151-207.

43. WOOD WA 1961 Fermentation of carbohydrates and related compounds. In: Gunsalus IC, Stanier RY (eds) The Bacteria. A Treatise on Structure and Function. Academic Press, New York, pp. 59-149. https://doi.org/10.1016/b978-0-12-395627-9.50010-4

44. DECKER K, JUNGERMAN K, THAUER RK 1970 Energy production in anaerobic organisms. Angew Chem Int Ed 9: 138-158. http://dx.doi.org/10.1002/anie.197001381

45. MÜLLER M, MENTEL M, VAN HELLEMOND JJ, HENZE K, WOEHLE C, GOULD SB, YU R-Y, VAN DER GIEZEN M, TIELENS AGM, MARTIN WF 2012 Biochemistry and evolution of anaerobic energy metabolism in eukaryotes. Microbiol Mol Biol Rev 76: 444-495. http://dx.doi.org/10.1128/MMBR.05024-11

46. BUCKEL W, THAUER RK 2013 Energy conservation via electron bifurcating ferredoxin reduction and proton $/ \mathrm{Na}^{+}$translocating ferredoxin oxidation. Biochim Biophys Acta 1827: 94-113. http://dx.doi.org/10.1016/j.bbabio.2012.07.002

47. SCHUCHMANN K, MU“LLER V 2014 Autotrophy at the thermodynamic limit of life: A model for energy conservation in acetogenic bacteria. Nat Rev Microbiol 12: 809-821. http://dx.doi.org/10.1038/nrmicro3365 
48. ADAMS MWW, HOLDEN JF, LAL MENON A, SCHUT GJ, GRUNDEN AM, HOU C, HUTCHINS AM, JENNEY JR. FE, KIM C, MA K, PAN G, ROY R, SAPRA R, STORY SV, VERHAGEN MFJM 2001 Key role for sulfur in peptide metabolism and in regulation of three hydrogenases in the hyperthermophilic archaeon Pyrococcus furiosus. J Bacteriol 183: 716-724. http://dx.doi.org/10.1128/JB.183.2.716-724.2001

49. MAI X, ADAMS MW 1996 Purification and characterization of two reversible and ADP-dependent acetyl coenzyme A synthetases from the hyperthermophilic archaeon Pyrococcus furiosus. J Bacteriol 178: 5897-5903. https://doi.org/10.1128/jb.178.20.5897-5903.1996

50. SCHÖNHEIT P, BUCKEL W, MARTIN WF 2016 On the origin of heterotrophy. Trends Microbiol 24: 12-25. http://dx.doi.org/10.1016/j.tim.2015.10.003

51. LANE N, ALLEN JF, MARTIN W 2010 How did LUCA make a living? Chemiosmosis in the origin of life. BioEssays 32: 271-280. http://dx.doi.org/10.1002/bies.200900131

52. SLEEP NH, BIRD DK, POPE EC 2011 Serpentinite and the dawn of life. Philos Trans R Soc Lond B Biol Sci 366: 2857-2869. http://dx.doi.org/10.1098/rstb.2011.0129

53. CHYBA CF, THOMAS PJ, BROOKSHAW L, SAGAN C 1990 Cometary delivery of organic molecules to the early Earth. Science 249: 366-373. https://doi.org/10.1126/science.11538074

54. SEPHTON MA 2002 Organic compounds in carbonaceous meteorites. Nat Prod Rep 19: 292-311. https://doi.org/10.1039/b103775g

55. DE DUVE, C 1991 Blueprint for a Cell: The Nature and Origin of Life. Neil Patterson Publishers, Burlington, North Carolina.

56. NITSCHKE W, RUSSELL MJ 2013 Beating the acetyl coenzyme A-pathway tot he origin of life. Philos Trans R Soc Lond B Biol Sci 368: 20120258. http://dx.doi.org/10.1098/rstb.2012.0258

57. AMEND JP, MCCOLLOM TM 2009 Energetics of biomolecule synthesis on early Earth. In: Zaikowski L, Friedrich JM, Russell Seidel S (eds) Chemical evolution II: From the origins of life to modern society. American Chemical Society, Washington, DC, pp. 63-94.

58. FUCHS G, STUPPERICH E 1985 Evolution of autotrophic $\mathrm{CO}_{2}$ fixation. In: Schleifer KH, Stackebrandt E (eds) Evolution of prokaryotes. FEMS Symposium No. 29, Academic Press, London, UK, pp. 235-251.

59. FUCHS G, STUPPERICH E 1986 Carbon assimilation pathways in archaebacteria. System Appl Microbiol 7: 364-369. http://dx.doi.org/10.1016/S0723-2020(86)80035-2

60. SHOCK EL, MCCOLLOM T, SCHULTE MD 1998 The emergence of metabolism from within hydrothermal systems. In: Wiegel J, Adams MWW (eds) Thermophiles: The keys to molecular evolution and the origin of life. Taylor and Francis, London, UK, pp. 59-76.

61. BACH W, PAULICK H, GARRIDO CJ, ILDEFONSE B, MEURER WP, HUMPHRIS SE 2006 Unraveling the sequence of serpentinization reactions: Petrography, mineral chemistry, and petrophysics of serpentinites from MAR $15^{\circ}$ N (ODP Leg 209, Site 1274). Geophys Res Lett 33: L13306. http://dx.doi.org/10.1029/2006GL025681

62. SLEEP NH, MEIBOM A, FRIDRIKSSON T, COLEMAN RG, BIRD DK $2004 \mathrm{H}_{2}$-rich fluids from serpentinization: Geochemical and biotic implications. Proc Natl Acad Sci US A 101: 12818-12823. http://dx.doi.org/10.1073/pnas.0405289101

63. RUSSELL MJ, HALL AJ, MARTIN W 2010 Serpentinization as a source of energy at the origin of life. Geobiol 8: 355-371. http://dx.doi.org/10.1111/j.1472-4669.2010.00249.x

64. ZAHNLE K, ARNDT N, COCKBELL C, HALLIDAY A, NISBET E, SELSIS F, SLEEP NH 2007 Emergence of a habitable planet. http://dx.doi.org/10.1007/s11214-007-9225-z
65. THAUER RK, KASTER AK, SEEDORF H, BUCKEL W, HEDDERICH R 2008 Methanogenic archaea: Ecologically relevant differences in energy conservation. Nat Rev Microbiol 6: 579-591. http://dx.doi.org/10.1038/nrmicro1931

66. BASEN M, MÜLLER V 2016 "Hot" acetogenesis. Extremophiles 1-12. http://dx.doi.org/10.1007/s00792-016-0873-3

67. SCHRENK MO, BRAZELTON WJ, LANG SQ 2013 Serpentinization, carbon, and deep life. Rev Mineral Geochem 75: 575-606. http://dx.doi.org/10.2138/rmg.2013.75.18

68. LANE N, MARTIN WF 2012 The origin of membrane bioenergetics. Cell 151: 1406-1416. http://dx.doi.org/10.1016/j.cell.2012.11.050

69. MARTIN W, RUSSELL MJ 2007 On the origin of biochemistry at an alkaline hydrothermal vent. Phil Trans R Soc Lond B 362: 18871926. http://dx.doi.org/10.1098/rstb.2006.1881

70. FUCHS G 1994 Variations of the acetyl-CoA pathway in diversely related microorganisms that are not acetogens. In: Acetogenesis. Drake G (ed), Chapman and Hall, New York, NY, pp. 506-538. https://doi.org/10.1007/978-1-4615-1777-1_19

71. THAUER RK, JUNGERMANN K, DECKER K 1977 Energyconservation in chemotropic anaerobic bacteria. Bacteriol Rev 41: $100-180$.

72. WEISSE RH, FAUST A, SCHMIDT M, SCHÖNHEIT P, SCHEIDIG AJ (2016) Structure of NDP-forming acetyl-CoA synthetase ACD1 reveals a large rearrangement for phosphoryl transfer. Proc Natl Acad Sci US A 113: 519-528. http://dx.doi.org/10.1073/pnas.1518614113

73. MARTIN W, RUSSELL MJ 2003 On the origins of cells: A hypothesis for the evolutionary transitions from abiotic geochemistry to chemoautotrophic prokaryotes, and from prokaryotes to nucleated cells. Philos Trans R Soc Lond B 358: 59-83. http://dx.doi.org/10.1098/rstb.2002.1183

74. FERRY JG, HOUSE CH 2006 The step-wise evolution of early life driven by energy conservation. Mol Biol Evol 23: 1286-1292. http://dx.doi.org/10.1093/molbev/msk014

75. DANIEL SL, HSU T, DEAN SI, DRAKE HL 1990 Characterization of the $\mathrm{H}_{2}$ - and CO-dependent chemolithotrophic potentials of the acetogens Clostridium thermoaceticum and Acetogenium kivuit. J Bacteriol 172: 4464-4471. https://doi.org/10.1128/jb.172.8.4464-4471.1990

76. DEPPENMEIER U, MÜLLER V 2008 Life close to the thermodynamic limit: How methanogenic archaea conserve energy. In: Schäfer G, Penefsky HS (eds) Bioenergetics - Energy Conservation and Conversion, Results and Problems in Cell Differentiation Vol. 45, Springer, Berlin, pp. 123-152. https://doi.org/10.1007/400_2006_026

77. WEISS MC, SOUSA FL, MRNJAVAC N, NEUKIRCHEN S, ROETTGER M, NELSON-SATHI S, MARTIN WF 2016 The physiology and habitat of the last universal common ancestor. Nat Microbiol 1: 16116. http://dx.doi.org/10.1038/NMICROBIOL.2016.116

78. HERRMANN G, JAYAMANI E, MAI G, BUCKEL W 2008 Energy conservation via electron-transferring flavoprotein in anaerobic bacteria. J Bacteriol 190: 784-791. http://dx.doi.org/10.1128/JB.01422-07

79. LI F, HINDERBERGER J, SEEDORF H, ZHANG J, BUCKEL W, THAUER RK 2008 Coupled ferredoxin and crotonyl coenzyme A $(\mathrm{CoA})$ reduction with NADH catalyzed by the butyryl-CoA dehydrogenase/Etf complex from Clostridium kluyveri.J Bacteriol 190: 843-850. http://dx.doi.org/10.1128/JB.01417-07

80. METCALF, WW 2016 Classic Spotlight: Electron bifurcation, a unifying concept for energy conservation in anaerobes $J$ Bacteriol 198: 1358-1358. http://dx.doi.org/10.1128/JB.00185-16

81. BUCKEL W 2001 Unusual enzymes involved in five pathways of glutamate fermentation. Appl Microbiol Biotechnol 57: 263-273. https://doi.org/10.1007/s002530100773 
82. KASTER A-K, MOLL J, PAREY K, THAUER RK 2011 Coupling of ferredoxin and heterodisulfide reduction via electron bifurcation in hydrogenotrophic methanogenic archaea. Proc Natl Acad Sci US A 108: 2981-2986. http://dx.doi.org/10.1073/pnas.1016761108

83. SCHUT GJ, ADAMS MWW 2009 The iron-hydrogenase of Thermotoga maritima utilizes ferredoxin and NADH synergistically: A new perspective on anaerobic hydrogen production. J Bacteriol 191: 4451-44657. http://dx.doi.org/10.1128/JB.01582-08

84. LIPMANN F 1941 Metabolic generation and utilization of phosphate bond energy. Adv Enzymol 1: 99-162. https://doi.org/10.1002/9780470122464.ch4

85. ZIMORSKI V, KU C, MARTIN WF, GOULD SB 2014 Endosymbiotic theory for organelle origins. Curr Opin Microbiol 22: 38-48. http://dx.doi.org/10.1016/j.mib.2014.09.008

86. MARTIN W, MÜLLER M 1998 The hydrogen hypothesis for the first eukaryote. Nature 392: 37-41. http://dx.doi.org/10.1038/32096

87. WILLIAMS TA, FOSTER PG, COX CJ, EMBLEY TM 2013 An archaeal origin of eukaryotes supports only two primary domains of life. Nature 504: 231-236. http://dx.doi.org/10.1038/nature12779

88. SOUSA FL, NEUKIRCHEN S, ALLEN JF, LANE N, MARTIN WF 2016 Lokiarchaeon is hydrogen dependent. Nature Microbiol 1: 16034. http://dx.doi.org/10.1038/nmicrobiol.2016.34

89. VAN VALEN LM, MAIORANA VC 1980 The Archaebacteria and eukaryotic origins. Nature 287: 248-250. http://dx.doi.org/10.1038/287248a0

90. ALLEN JF 2005 A redox switch hypothesis for the origin of two light reactions in photosynthesis. FEBS Lett 579: 963-968. http://dx.doi.org/10.1016/j.febslet.2005.01.015

91. MARTIN W 1999 A briefly argued case that mitochondria and plastids are descendants of endosymbionts, but that the nuclear compartment is not. Proc R Soc Lond B 266: 1387-1395. http://dx.doi.org/10.1098/rspb.1999.0792

92. LANE N, MARTIN W 2010 The energetics of genome complexity. Nature 467: 929-934. http://dx.doi.org/10.1038/nature09486

93. KU C, NELSON-SATHI S, ROETTGER M, SOUSA FL, LOCKHART PJ, BRYANT D, HAZKANI-COVO E, MCINERNEY
JO, LANDAN G, MARTIN WF 2015 Endosymbiotic origin and differential loss of eukaryotic genes. Nature 524: 427-432. http:// dx.doi.org/10.1038/nature14963

94. MERESCHKOWSKY C 1905 Über Natur und Ursprung der Chromatophoren im Pflanzenreiche. (On the nature and origin of chromatophores (plastids) in the plant kingdom.) Biol Centralbl25: 593-604 [German].

95. MARTIN W, STOEBE B, GOREMYKIN V, HANSMANN S, HASEGAWA M, KOWALLIK KV 1998 Gene transfer to the nucleus and the evolution of chloroplasts. Nature 393: 162-165. http://dx.doi.org/10.1038/30234

96. MARTIN W, RUJANT, RICHLYE, HANSENA, CORNELSEN S, LINS T, LEISTER D, STOEBE B, HASEGAWA M, PENNY D 2002 Evolutionary analysis of Arabidopsis, cyanobacterial, and chloroplast genomes reveals plastid phylogeny and thousands of cyanobacterial genes in the nucleus. Proc Natl Acad Sci US A 99: 12246-12251. http://dx.doi.org/10.1073/pnas.182432999

97. MERESCHKOWSKY C 1910 Theorie der zwei Plasmaarten als Grundlage der Symbiogenesis, einer neuen Lehre von der Entstehung der Organismen. (Theory of two plasma types as the basis of symbiogenesis, a new theory of the origin of the organisms.) Biol Centralbl 30: 353-442 [German].

98. MCDERMOTT J, SEEWALD JS, GERMAN CR, SYLVA SP 2015 Pathways for abiotic organic synthesis at submarine hydrothermal fields. Proc Natl Acad Sci US A 112: 7668-7672. http://dx.doi.org/10.1073/pnas.1506295112

99. MARTIN WF 2012 Hydrogen, metals, bifurcating electrons, and proton gradients: The early evolution of biological energy conservation. FEBS Lett 586: 485-493. http://dx.doi.org/10.1016/j.febslet.2011.09.031

100. MARTIN WF, SOUSA FL 2015 Early microbial evolution: the age of anaerobes. Cold Spring Harbor Persp Biol 8: a018127. http://dx.doi.org/10.1101/cshperspect.a018127

101. MARTIN W, GARG S, ZIMORSKI V 2015 Endosymbiotic theories for eukaryote origin. Philos Trans R Soc Lond B 370: 20140330. http://dx.doi.org/10.1098/rstb.2014.0330 